\title{
INTRODUCTION OF BIO- FUNGICIDES FOR CONTROLLING POWDERY MILDEW DISEASE OF RAMBUTAN
}

\author{
P. W. Alahakoon, N. H. Jayawardana, K.C. Madushani and R.K.Nilmini \\ Fruit Crop Research and Development Center, Department of Agriculture, Horana, Sri Lanka. \\ E-mail-fcrdc@yahoo.com, Tel/Fax-++94342261323
}

\begin{abstract}
Powdery mildew of Rambutan (Nephelium lappaceum) incited by the fungus Oidium nephelii attack young leaves, flowers and immature fruits become dis-colored and dry off causing fruit quality deterioration and heavy fruit losses. Oidium nephelii is controlled by application of fungicides. An experiment was conducted to study the efficacy of plant extracts compared with the fungicides to control powdery mildew disease of Rambutan. The treatments consisted of eight plant extracts (Neem oil, Citronella oil, Cinnamon leaf extract (Cinnamomum zeylanicum), Clove leaf extract (Syzygium aromaticum), Naa leaf extract (Mesua nagassarium), Lime leaf extract (Citrus aurantifolia), Neem seed extract (Azadiracta indica), Vinegar (Cocos nucifera)) and two recommended fungicides Thiovit (wettable Sulphur) and Daconil (Chlorothalonil). Severity and spread of powdery mildew basically depends on the environment. Therefore selection of herbal extracts was done during heavy rain and in dry weather conditions. The results obtained from the experiment revealed that under the dry weather condition, the maximum number of healthy fruit set at harvest was given by the Citronella oil and Neem oil. The Clove leaf extract and Cinnamon leaf extract significantly controlled the powdery mildew disease than that of Department recommended fungicides .Neem seed extract and Vinegar controlled the disease similar to the Department recommended fungicides. In contrast to the data obtained under dry weather condition, in the heavy rain conditions, only the Citronella oil and Neem oil moderately increased the healthy fruit set at harvest. The plant extracts Neem oil, Citronella oil, Clove leaf extract, Cinnamon leaf extract controlled the disease than that of recommended fungicides and they can be used as the bio-fungicides. Bio-fungicides are eco-friendly and are not known to cause pollution to climate or soil.
\end{abstract}

Keywords:, Neem oil, Citronella oil, Cinnamon leaf extract, Clove leaf extract, Fungicides

\section{INTRODUCTION}

Powdery mildew of Rambutan (Nephelium lappaceum) incited by the fungus Oidium nephelii is controlled by the application of fungicides (Garcia, 1983; Rajapakse, 2006). Oidium nephelii attack young leaves, flowers and immature fruits become dis-colored and dried off causing fruit quality deterioration and heavy fruit losses.

Oidium nephelii is an obligatory parasite thus cannot be cultured on artificial nutrient media. They produce mycelium grows only on the surface of plant tissues and obtain nutrients through haustoria from the epidermal cells of the host. Mycelium produces short conidiophores on the plant surface. Each conidiophore produces chains of egg shaped conidia that are carried by air currents (Agrios, 1997; Rajapaksa, 2006). Severity and spread of powdery mildew disease basically depend on the environment.

Rambutan needs a critical dry period for flowering and to fruit set. Rambutan usually flowers and set-up fruits during the traditional dry period of February and March. But this traditional dry period go challenged with emerging threats of the climate change. The change in the weather pattern was to blame for the powdery mildew fungal attack on the rambutan trees.

According to the agricultural department statistics, the rainfall figures well demonstrate that during the particular period in 2008 , in rambutan growing areas, had received twice as much as rainfall, the areas usually get drastically reducing the rambutan yield. The rambutans have only one annual harvesting season and therefore when the crop failed due to unusual changes

Proceedings of the International Forestry and Environment Symposium 2010 of the Department of Forestry and Environmental Science, University of Sri Jayewardenepura, Sri Lanka. 
in the climate make their growers desperate. The growers in these areas patiently wait year after year hoping to see a flourishing yield, each passing year they become more distressed to see being let down by the climate.

According to the Department of Agriculture recommendations powdery mildew is controlled with spraying of wettable sulphur (contact) or chlorothalonil, (contact) or Thiophanate methyl (Systemic) fungicide. Additionally removing of unwanted branches like water shoots, dead woods to open the canopy for sun light and to improve ventilation within the canopy are included.

Although the chemical application is the most common conventional means to control fungal diseases in crops, it is also a well-known fact, that chemical control creates a lot of problems in humans and other organisms as well as degrades the environment. Application of fungicides can cause negative effects such as development of pathogen resistance, harm on environment friendly organisms and difficulties in the disposal of fungicides and they are harmful to consumers since they accumulate in the product. Therefore new environment safe technologies should be introduced to replace the existing harmful ones. Bio-fungicides are one of them. Many microbes antagonist to plant pathogens have been proved to be effective against many diseases. Plant extracts are other resource to use for this purpose. Bio-fungicides are eco-friendly and are not known to cause pollution to climate or soil. Therefore biofungicides were tested to control powdery mildew disease of Rambutan.

Severity and spread of powdery mildew disease basically depends on the environment. The change in the weather pattern was to blame for the inability in the control of powdery mildew disease. In the past years, flowering and fruit set occurred during heavy rain condition. Therefore selection of bio-fungicides (plant extracts) was done during heavy rain and in dry weather condition.

\section{MATERIALS AND METHODS}

\subsection{LOCATION}

The experiment was conducted at the Fruit Crop Research and Development Center, Horana in the 2009 to study the efficacy of plant extracts compared with the Department of Agriculture recommended fungicides to control powdery mildew disease of Rambutan during heavy rain and in dry weather condition.

The area of the field block used for this experiment was established by 1985 budded "Malwana Special" variety trees at a spacing of $10 \mathrm{~m}$ x $10 \mathrm{~m}$. Rainfall data was collected from the Fruit Crop Research and Development Center, Horana.

\subsection{PLANT EXTRACTS TREATMENT}

The treatments consist of eight plant extracts (Neem oil (commercial product), Citronella oil (commercial product), Cinnamon leaf extract (Cinnamomum zeylanicum), Clove leaf extract (Syzygium aromaticum), Naa leaf extract (Mesua nagassarium), Lime leaf extract (Citrus aurantifolia), Neem seed extract (Azadiracta indica), Vinegar (Cocos nucifera)) and two recommended fungicides Thiovit (wettable Sulphur) and Daconil (Chlorothalonil). Leaf extracts of Cinnamon, Clove, Naa and Lime leaves were obtained by macerating $250 \mathrm{~g}$ fresh leaves in $1000 \mathrm{ml}$ distilled water in an electric blender at a speed of $21,000 \mathrm{rpm}$ for two minutes and then straining. Neem oil, Citronella oil, vinegar (palm production) were taken from commercial products and sprayed at the rate of $2 \mathrm{ml} / \mathrm{L}$; Neem seed at the rate of $200 \mathrm{~g}$ macerated seeds/1L water was used. Three controls were used, one as sprayed water and others as Thiovit (wettable Sulphur) and Daconil (Chlorothalonil). Plant extracts were sprayed during heavy rain condition as well as under the dry weather condition.

Proceedings of the International Forestry and Environment Symposium 2010 of the Department of Forestry and Environmental Science, University of Sri Jayewardenepura, Sri Lanka. 
The sample size was two "Malwana Special"rambutan budded trees per treatment including three branches treated. The experiment was arranged as Randomized Complete Block Design with five replicates. Plant extracts and fungicides were sprayed three times at 12 day intervals, because of heavy rains.

From each side of the tree, three branches were treated. Branches bearing fruits at growth stage, $20 \%$ with visible of mildew, were selected and tagged with numbered plastic labels. Tagging was colour-coded according to the treatment.

Fungicide and water spraying was carried-out early in the morning when the wind was not strong, to avoid chemical drift. Spraying was done using a manual pump action sprayer (1L capacity) at 12 day intervals. During spraying a panicle was held and sprayed $40 \mathrm{~cm}$ away from the nozzle; one spray jet per panicle was adequate to achieve good cover.

\subsection{MILDEW ASSESSMENT AND DATA PROCESSING}

Starting from the first disease symptoms appeared on branches having panicles bearing immature fruits, growth stage at $20 \%$, was assessed for mildew infection. Each tagged branch having panicles was assessed for mildew infection at weekly intervals. The spray programme was started when mildew infection levels on all trees reached $100 \%$ without fungicide application. Mildew infection was indicated by the presence of mycelial growth and sporulation on the tissue surface and was clearly distinguished from tissue discolouration due to physiological decay.

Concurrent with assessment of mildew severity, the number of fruit set and the maximum number of fruits formed per branch at harvest were used as yield parameters. Fruit weights were not recorded. Analysis of variance was used to compare data on fruit formation.

\section{RESULTS AND DISCUSSION}

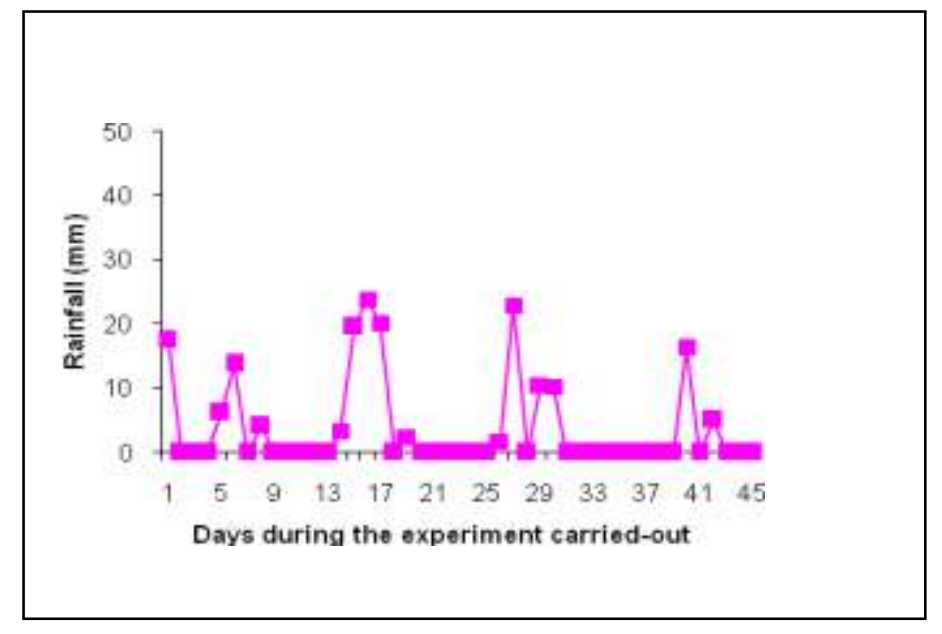

Figure 1: Rainfall data in dry weather condition (FCRDC, Meteorological center) during the experiment carried -out 
Table 1: Mean percentage healthy fruits at harvest after treating with different plant extracts during dry weather

\begin{tabular}{lc}
\hline \multicolumn{1}{c}{ Plant extract } & $\begin{array}{c}\text { Mean percentage healthy fruits at } \\
\text { harvest }\end{array}$ \\
\hline Citronella oil & $95.65^{\mathrm{a}}$ \\
Neem oil & $94.74^{\mathrm{a}}$ \\
Clove leaf extract & $87.93^{\mathrm{b}}$ \\
Cinnamon leaf extract & $87.90^{\mathrm{b}}$ \\
Neem seed extract & $78.90^{\mathrm{c}}$ \\
Vinegar & $78.06^{\mathrm{c}}$ \\
Lime leaf extract & $78.05^{\mathrm{c}}$ \\
Naa leaf extract & $58.01^{\mathrm{d}}$ \\
Sulphur (Thiovit) & $78.77^{\mathrm{c}}$ \\
Daconil (Chlorothalonil) & $77.25^{\mathrm{c}}$ \\
Control (water) & $55.05^{\mathrm{d}}$ \\
LSD & 5.82 \\
CV\% & 10.06 \\
\hline
\end{tabular}

Means followed by the same letter within a column are not significantly different at $\mathrm{P}=0.01$

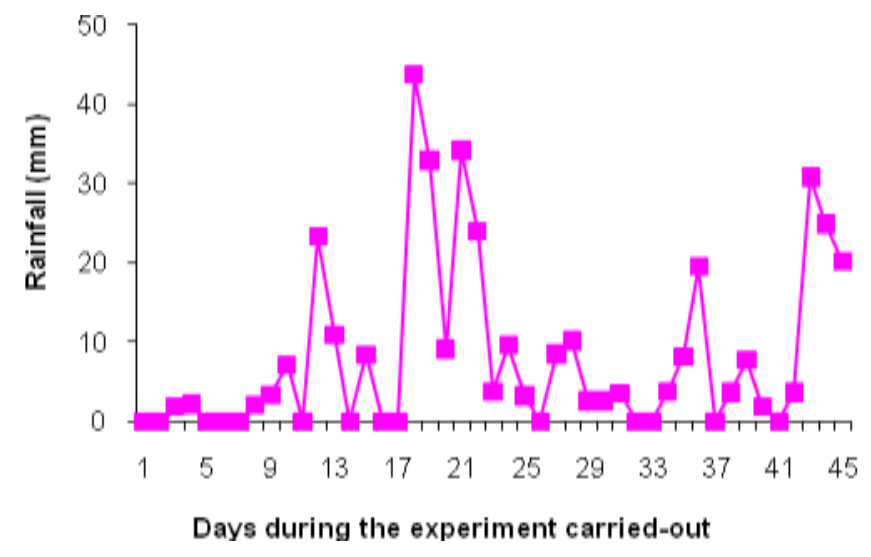

Figure 2: Rainfall data in wet weather condition (FCRDC, Meteorological center) during the experiment carried -out 
Table 2: Mean percentage healthy fruits at harvest after treating with different plant extracts during heavy rains

\begin{tabular}{cc}
\hline Plant extract & $\begin{array}{c}\text { Mean percentage } \\
\text { healthy fruits at harvest }\end{array}$ \\
\hline Citronella oil & $49.65^{\mathrm{a}}$ \\
Neem oil & $46.74^{\mathrm{a}}$ \\
Clove leaf extract & $12.01^{\mathrm{b}}$ \\
Cinnamon leaf extract & $10.75^{\mathrm{b}}$ \\
Neem seed extract & $3.90^{\mathrm{b}}$ \\
Vinegar & $6.04^{\mathrm{b}}$ \\
Naa leaf extract & $6.01^{\mathrm{b}}$ \\
Lime leaf extract & $6.09^{\mathrm{b}}$ \\
Sulphur (Thiovit) & $7.77^{\mathrm{b}}$ \\
Daconil (Chlorothalonil) & $9.10^{\mathrm{b}}$ \\
Control (water) & $6.06^{\mathrm{b}}$ \\
LSD & 12.01 \\
CV\% & 11.82 \\
\hline
\end{tabular}

Means followed by the same letter within a column are not significantly different at $\mathrm{P}=0.01$

3.1. VARIATION IN THE RESPONSE OF PLANT EXTRACTS TO CONTROL According to the data (Table 1 and fig. 1) obtained under the dry weather condition, the maximum number of healthy fruit set at harvest was given by the Citronella oil and Neem oil. Clove leaf extract and Cinnamon leaf extract significantly controlled the disease than other plant extracts. Neem seed extract, Lime leaf extract and Vinegar controlled the disease and increased the healthy fruit production similar to the Department of Agriculture recommended fungicides, Thiovit and Daconil.

In contrast to the data obtained under dry weather condition, in the heavy rain condition (Table 2 and fig. 2), Citronella oil and Neem oil moderately increased healthy fruit set at harvest while the other plant extracts like Clove, Cinnamon, Naa, Lime leaf extracts, Neem seed extract and Vinegar failed to control the powdery mildew disease similar to Department recommended fungicides.

The experiment confirmed that the severity and spread of powdery mildew disease basically depended on the environment (similar observations were recorded by Sijaona et al., 2001 and Waller et al., 1992). Heavy rain condition, Department recommended fungicides failed to control the powdery mildew disease. Citronella oil and Neem oil efficiently controlled the powdery mildew gaining the highest number of healthy fruits at harvest under dry weather condition. Even under heavy rain condition, Citronella oil and Neem oil moderately control the disease than any other plant extract or Department recommended fungicides.

Singh and Prithiviraj (1997) have reported that a product of Neem significantly retarded conidia differentiation and symptom development of powdery mildew caused by Erysiphe on pea plants. This result is comparable to the data obtained in our experiment although the weather condition was not mentioned.

Proceedings of the International Forestry and Environment Symposium 2010 of the Department of Forestry and Environmental Science, University of Sri Jayewardenepura, Sri Lanka. 


\section{CONCLUSION}

Among the plant extracts and department recommended fungicides, only Neem oil and Citronella oil moderately controlled the powdery mildew during heavy rains but they were highly effective in controlling the disease under the dry weather condition. Cinnamon and Clove leaf extracts controlled the disease successfully than the department recommended fungicides under the dry weather condition. Neem seed extract Lime leaf extract and Vinegar controlled the disease similarly to Department recommended fungicides. Naa leaf extract had no effect on controlling the disease.

\section{REFERENCES}

Agrios, G.N. 1997. Plant Pathology. Academic Press, London, U.K. Pp 295-298.

Garcia, A.S. 1983. The Powdery mildew disease of rambutan. Philippine Phytopathology 19:15-16.

Rajapakse, R.G.A.S., E.R.S.P Edirimanna,.and J.Kahawatta. 2006. Management of powdery mildew disease of rambutan (Nephelium lappacum L.) in Sri Lanka. The journals of agricultural sciences of the Sabaragamuwa University of Sri Lanka 2 (3): 8 -15.

Sijaona, M.E.R., A. Clewer, A. Maddision and J. W. Mansfield. 2001. Comparative analysis of powdery mildew development on leaves, seedlings and flower panicles of different genotype of Cashew. Plant Pathology 50: 234-243.

Singh, U.P.and B. Prithiviraj. 1997. Neemzal, a product of neem (Azadirachia indica) induces resistance in Pea (Pisium sativum) against Erysiphe pisi. Physiological and Molecular plant pathology $51: 181-194$

Waller, J. M., N. Q. R. Nathaniels, M.E.R .Sijaona and S.H. Shomari., 1992. Cashew powdery mildew (Oidium anacardii Noac.) in Tanzania, Tropical Pest Management 38: 160-163. 